Nat. Hazards Earth Syst. Sci., 19, 1471-1483, 2019

https://doi.org/10.5194/nhess-19-1471-2019

(C) Author(s) 2019. This work is distributed under

the Creative Commons Attribution 4.0 License.

\title{
Update of the tsunami catalogue of New Caledonia using a decision table based on seismic data and marigraphic records
}

\author{
Jean Roger ${ }^{1}$, Bernard Pelletier ${ }^{2}$, and Jérôme Aucan ${ }^{1}$ \\ ${ }^{1}$ LEGOS, Institut de Recherche pour le Développement, 101, Promenade Roger Laroque, \\ BP A5 98848 Nouméa CEDEX, France \\ ${ }^{2}$ GEOAZUR, Institut de Recherche pour le Développement, 101, Promenade Roger Laroque, \\ BP A5 98848 Nouméa CEDEX, France
}

Correspondence: Jean Roger (jeanrog@ hotmail.fr)

Received: 8 February 2019 - Discussion started: 26 February 2019

Revised: 11 June 2019 - Accepted: 21 June 2019 - Published: 22 July 2019

\begin{abstract}
Fourteen years ago, the 26 December 2004 Indian Ocean tsunami demonstrated the destructional capability of tsunamis to the entire world. Since then, many research programs have been initiated to try to understand the phenomenon and its related hazards better and to improve the early warning systems for exposed coastal populations. Pacific Islands Countries and Territories (PICTs) are especially vulnerable to tsunamis. Amongst them, New Caledonia is a French overseas territory located in the Southwest Pacific and exposed to several tsunami sources. In 2010, a catalogue of tsunamis that were visually observed or measured in New Caledonia was published. Since this first study, several events occurred between 2009 and 2019, and an update of this catalogue was necessary within the framework of a tsunami hazard assessment project in New Caledonia (TSUCAL). To complete this catalogue, a decision table has been designed to select potential tsunamigenic events within the USGS earthquake database, using criteria on the distance to New Caledonia, the magnitude and the hypocenter depth. Then a crosscomparison between these earthquakes, the NOAA National Geophysical Data Center (NGDC) tsunami catalogue and local tide gauge records provided 25 events that were recorded in New Caledonia for the period from 30 September 2009 to 10 January 2019. These events are added to the 12 events reported with certainty during previous studies, leading to a number of 37 tsunamis triggered by earthquakes reported or recorded in New Caledonia since 1875. Six of them have been identified only thanks to local tide gauges, supporting the fact that instrumental recording of tsunamis is paramount for tsunami hazard studies, from early warning to the valida-
\end{abstract}

tion of coastal models. In addition, unpublished tide gauge data are provided for the 1960 Chile tsunami.

\section{General settings}

New Caledonia is located $\sim 200 \mathrm{~km}$ of the Vanuatu subduction zone in the Southwest Pacific Ocean between Australia and Vanuatu (Fig. 1). This subduction zone is part of the Pacific-Australian ( $\mathrm{P}-\mathrm{A})$ plates' boundary that runs from New Zealand to the south to Papua New Guinea to the north. Along this boundary the convergence rate between the Australian and Pacific plates has been estimated to 60 $120 \mathrm{~mm} \mathrm{yr}^{-1}$ (DeMets et al., 2010). However due to several microplates being located between the two major plates and due especially to back-arc spreading, convergence rates at trenches can largely exceed the $\mathrm{P}-\mathrm{A}$ motion, and these rates were measured as being up to $17 \mathrm{~cm} \mathrm{yr}^{-1}$ in northern Vanuatu and $24 \mathrm{~cm} \mathrm{yr}^{-1}$ in northern Tonga (Pelletier and Louat, 1989; Bevis et al., 1995; Pelletier et al., 1998; Calmant et al., 2003). Over the past decades, this convergence zone has clearly demonstrated its ability to generate strong shallow earthquakes. Moment magnitude does not exceed 8.2 according to the USGS catalogue, but events with magnitude above 8.2 are possible due to both the size of subduction segments and the very rapid relative plate motion.

New Caledonia is an archipelago that was originally populated by Austronesians circa 3000 years ago (Forestier, 1994). It was discovered by Europeans on 4 September 1774 (Faivre, 1950). But according to the same author, foreigners 


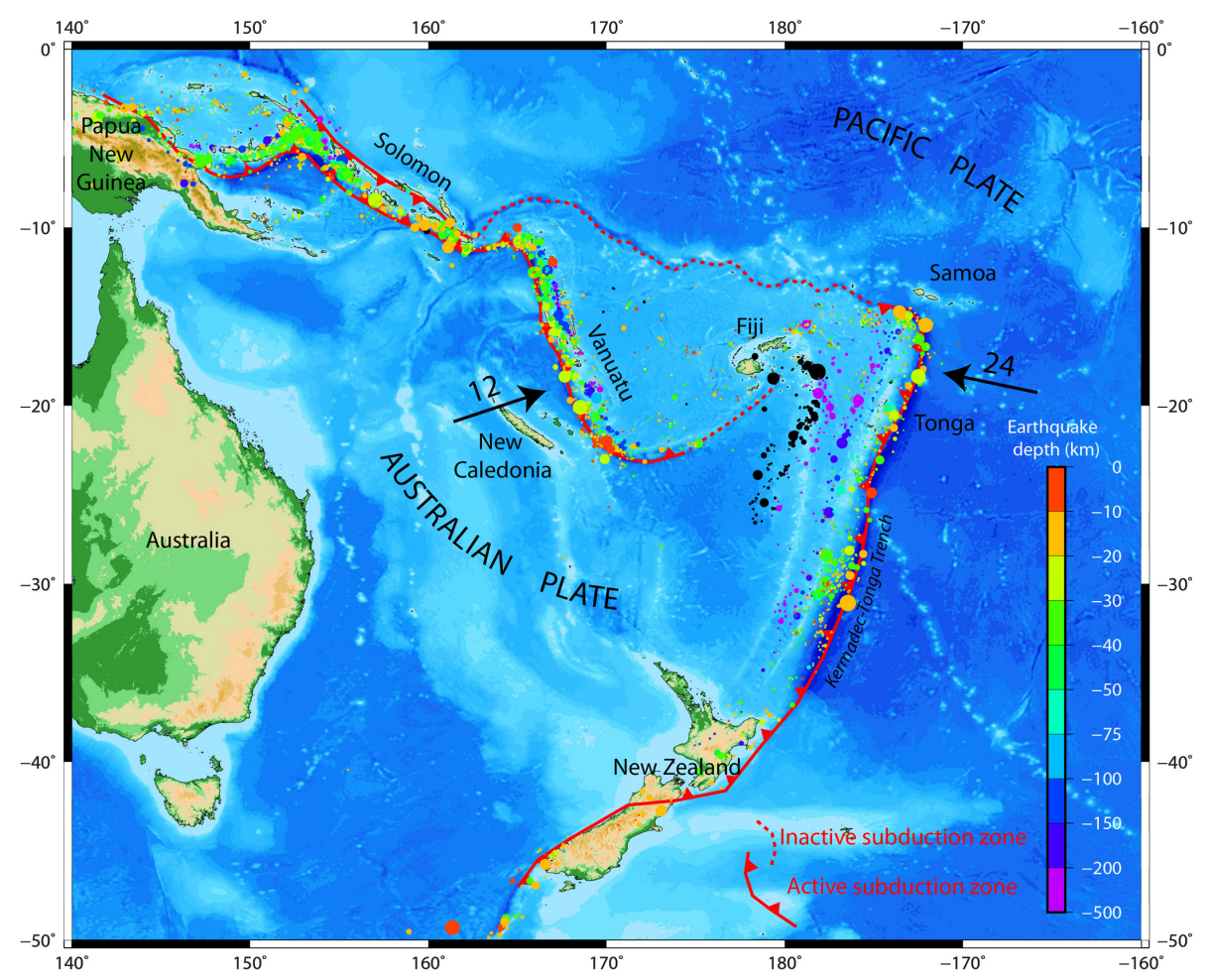

Figure 1. Regional tectonic settings around New Caledonia. The colored dots represent $M_{\mathrm{W}} \geq 6.3$ earthquakes recorded since 1 January 1900 , and their sizes are a function of magnitude. The black arrows symbolize the relative motion of the Australian and Pacific plates ( $\mathrm{cm}^{-1}$ ).

really began to settle here only after 1840 , when they began to write reports of uncommon natural phenomena, including tsunamis. Thus, the reported written history of tsunamis only covers the last 180 years, and there is only information available for the biggest events, especially when associated with an earthquake felt by the population; it concerns mainly earthquakes occurring in the Vanuatu subduction zone. In addition, due to its oceanic location, New Caledonia is also exposed to tsunamis coming from other parts of the Pacific Ocean, from regional sources (e.g., Solomon and Tonga-Kermadec trenches; Fig. 1) to transoceanic sources (e.g., Chile, Japan or Kuril subduction zones). Most of the time these tsunamis have been reported in coeval reports by witnesses or transmitted orally in the Kanak tradition and collected in a catalogue by Sahal et al. (2010) for the period running from 1875 to 2009 as an update of the previous catalogues from Soloviev and Go (1974) and Louat and Baldassari (1989).

The present study builds on the catalogue from Sahal et al. (2010) using a decision table and local marigraphic data, adding events that have been recorded since then and adding new information concerning previously mentioned events as, for example, the 1960 Chile tsunami.

\section{Methodology}

This study is based on the USGS earthquake catalogue that provides accurate information on seismic events that have occurred all around the world since 1 January 1900 (US Geological Survey, 2019). A decision table has been created to select the events within this database that were potentially tsunamigenic and had potential to reach the New Caledonia coastlines. The events extracted are then cross-compared to the tsunamis reported from the NOAA National Geophysical Data Center (NGDC) tsunami database and the NOAA Pacific Tsunami Warning Center (PTWC) bulletin archives and to local marigraphic data.

\subsection{Data selection with magnitude criteria}

The first step was to collect all the available earthquakes from the catalogue for the Pacific Ocean region. We decided to select only the $M_{\mathrm{w}}>6.3$ events according to global tsunami databases, like the Historical Tsunami Database for the World Ocean (HTDB/WLD; http://tsun. sscc.ru/tsunami-database/index.php, last access: 21 January 2019) or the NOAA NGDC/WDS Global Historical Tsunami Database (https://www.ngdc.noaa.gov/hazard/tsu_ db.shtml, last access: 24 August 2018), which empirically show that there is no tsunami triggered by earthquakes of magnitude $M_{\mathrm{w}}<6.3$ (Tinti, 1991). Further, Bolt et al. (1975) 
indicate that the maximum run-up for a tsunami generated by a $M_{\mathrm{w}}=6.5$ earthquake would be no more than $0.5-$ $0.75 \mathrm{~m}$, and Walker (2005) shows that tsunamigenic earthquakes with moment magnitudes $M_{\mathrm{w}} \geq 8.6$ all had a Pacificwide impact. On 10 January 2019, this collection represents $4902 M_{\mathrm{w}} \geq 6.3$ earthquakes that have occurred in the whole Pacific Ocean (considered box: $66.2^{\circ} \mathrm{S}, 62^{\circ} \mathrm{N}, 118.4^{\circ} \mathrm{W}$, $297.8^{\circ} \mathrm{W}$ ) since 29 July 1900.

Then it is important to select events able to trigger tsunami with sufficient energy to reach New Caledonia. Ward (1980) has indicated that tsunami generation is dependent upon the following criteria: the faulting mechanisms (mainly dip and slip), the magnitude (energy release) and the epicenter depth (focal depth). Thus, we consider all the faulting mechanisms without any distinction, integrating the distance from the source to New Caledonia with the earthquake magnitude and epicenter depth in the decision table.

Note that the global tsunami catalogue is considered as a whole, and not only in the Pacific Ocean region, according to the fact that catastrophic events like the 2004 Sumatra (Indian Ocean) tsunami could be recorded by tide gauges all around the world (Titov et al., 2005; Rabinovich and Thomson, 2007).

\subsection{The faulting mechanisms}

Although thrust and normal faults are responsible for the majority of strong subduction earthquakes and tsunamis, Tanioka and Satake (1996) have shown that in a specific case, i.e., when the rupture occurs on a steep slope with a horizontal displacement significantly larger than the vertical displacement, strike-slip faulting is also able to trigger a tsunami. In addition, Legg and Borrero (2001) and Borrero et al. (2004) have also shown that tectonic events occurring on strike-slip faults with sinuous traces could trigger tsunamis through the effect of uplift and subsidence along compressional and extensional relays. Thus, we decided to consider all faulting mechanisms because they are all potentially able to exhibit a vertical component of ocean bottom disturbance, the only parameter required to disturb the water column and generate a tsunami.

\subsection{Relationship between earthquake magnitude and focal depth and tsunami generation}

We use the data from the NOAA NGDC/WDS Global Historical Tsunami Database to plot the earthquake focal depth as a function of magnitude for 440 tsunamigenic earthquakes that occurred around the world from 1 January 1970 to $24 \mathrm{Au}-$ gust 2018 (Fig. 2). Only $47(10.7 \%)$ of these events have $M_{\mathrm{W}}<6.3$, and $9(2.0 \%)$ have been located at a depth of more than $100 \mathrm{~km}$. Considering that these events are not located within the Pacific Ocean, and/or they did not produce a sufficient tsunami to be recorded in New Caledonia, we decided to only look at earthquakes of magnitude $M_{\mathrm{w}}>6.3$ and fo- cal depth $<100 \mathrm{~km}$ in the following. Note that these values are consistent with different early warning systems' criteria (Tinti, 1991; UNESCO/IOC, 2009).

\subsection{Tsunami amplitude and distance from the source}

The tsunami amplitude, its wavelength and its frequency components, directly linked to the earthquake magnitude and focal mechanism and rupture dynamics, determine the extent of the impacted zone: local, regional or ocean-wide impact. In fact, a tsunami triggered by a landslide or a moderate earthquake is more inclined to reflect a dispersive phenomenon than a tsunami triggered by a large earthquake because dispersion is directly linked to the wavelength and frequency content, the water depth and the propagation distance (Glimsdal et al., 2013). In fact, the smaller the source, the quicker the energy decay and finally the disappearance of the tsunami waves over the time and distance from the source (Rabinovich et al., 2013). For example, Tanioka et al. (2018) show the role of this dispersion phenomenon when looking at the DART buoy record of the tsunami triggered by the $M_{\mathrm{w}}=6.92016 \mathrm{El}$ Salvador-Nicaragua earthquake: in that specific case, the linear long-wave theory overestimates the numerical modeling results considerably in comparison to the results obtained with the help of linear Boussinesq equations, taking into account the dispersion effect.

We decided to sort events depending on magnitude and distance criteria of $D=2500 \mathrm{~km}$ and $M=7.5$ because (i) the local and regional sources (from the Solomon, Vanuatu and Tonga-Kermadec subduction zones) are located within a circle of $\sim 2500 \mathrm{~km}$ radius (Fig. 3) and (ii) the far-field potential tsunami triggered by earthquakes of moment magnitude below 7.5 could not be recorded in New Caledonia according to historical data, and far-field sources could only be located between $4400 \mathrm{~km}$ (for the Mariana Trench, offshore Guam) and more than $10000 \mathrm{~km}$ away from New Caledonia (for the Chile subduction zone).

\subsection{Construction of the decision table}

The decision table is based on the previous explanations and lays down the rules to keep or reject a considered event from the USGS catalogue with respect to specific conditions on three different parameters: the earthquake magnitude $(M)$, the focal depth $(F)$ and the distance between the source and New Caledonia $(D)$. Four cases are considered to select whether an event is kept or rejected. They are summarized in Fig. 4.

For the calculations of distance from an earthquake epicenter to New Caledonia on a sphere, an approximate theoretical center of New Caledonia has been determined calculating the barycenter of a triangle with the three following points: $\left[163.576030^{\circ},-19.539454^{\circ}\right.$ ] for the northernmost point of the archipelago, $\left[167.570644^{\circ},-22.762149^{\circ}\right]$ for the southernmost point and $\left[168.135799^{\circ},-21.450552^{\circ}\right]$ 


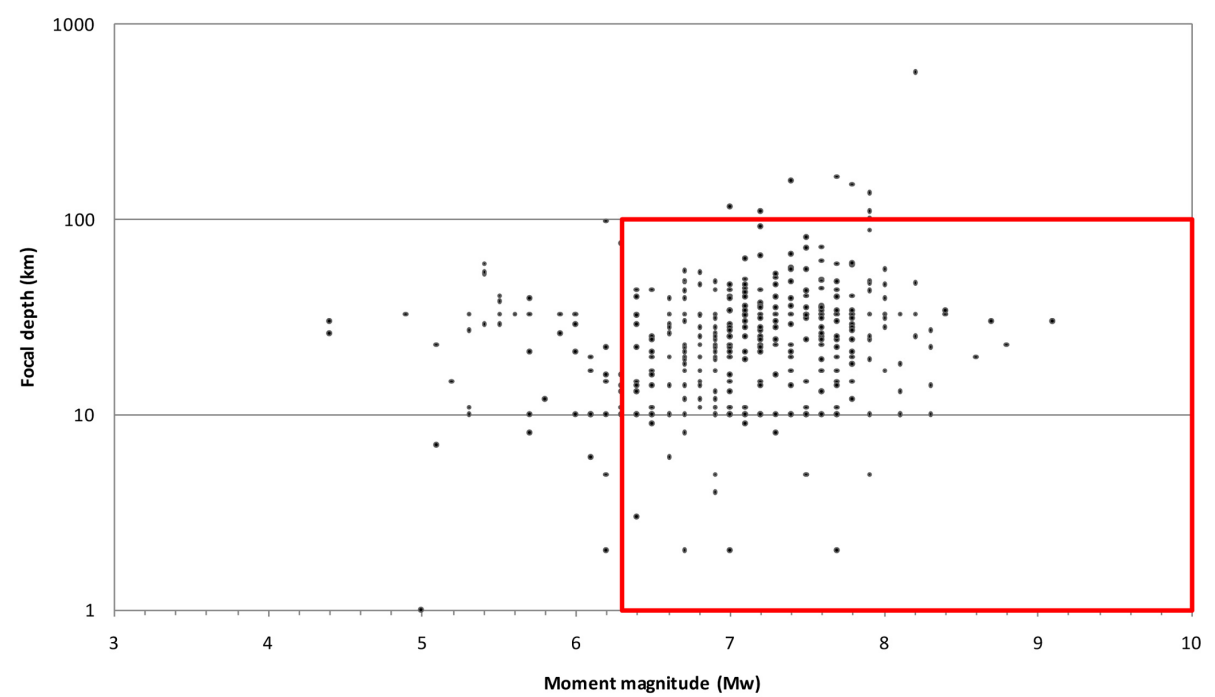

Figure 2. Relationship between earthquake focal depth and moment magnitude for 440 tsunamigenic events of the NGDC/WDS Global Historical Tsunami Database.

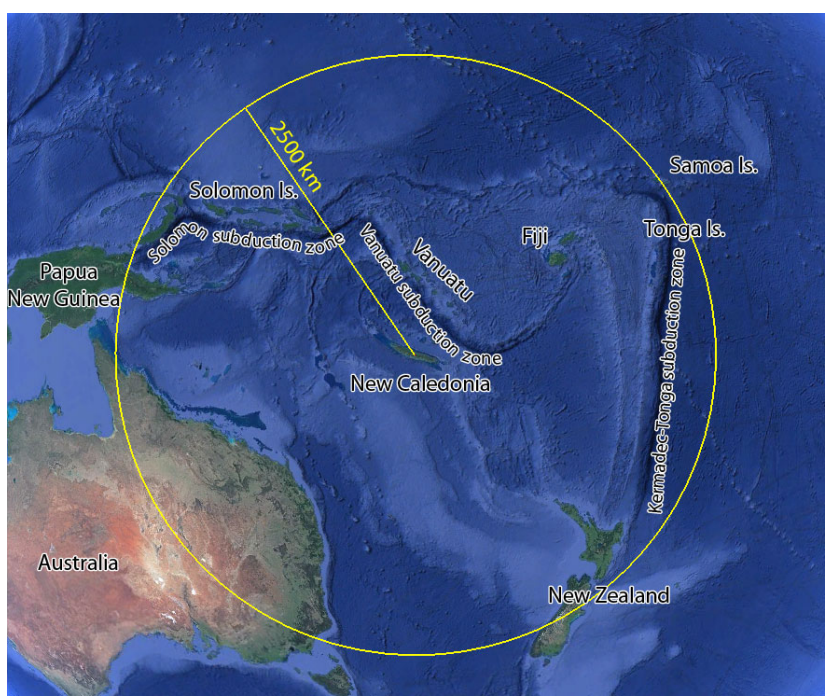

Figure 3. $2500 \mathrm{~km}$ around New Caledonia (credit: (C) Google 2018, Landsat/Copernicus image).

for the easternmost point. Its coordinates are $\left[166.427491^{\circ}\right.$, $\left.-21.250718^{\circ}\right]$.

\subsection{Sea-level data}

The tide gauge stations of New Caledonia are located in Fig. 5. All the tide gauges were installed along the east coast of the Grande Terre of New Caledonia and on the Loyalty Islands, except the historical tide gauge in Nouméa (Chaleix then Numbo), the capital located on the west coast of Grande Terre. Instrumental records of hourly sea level for Nouméa extend back to 1957 (Aucan et al., 2017a), and in

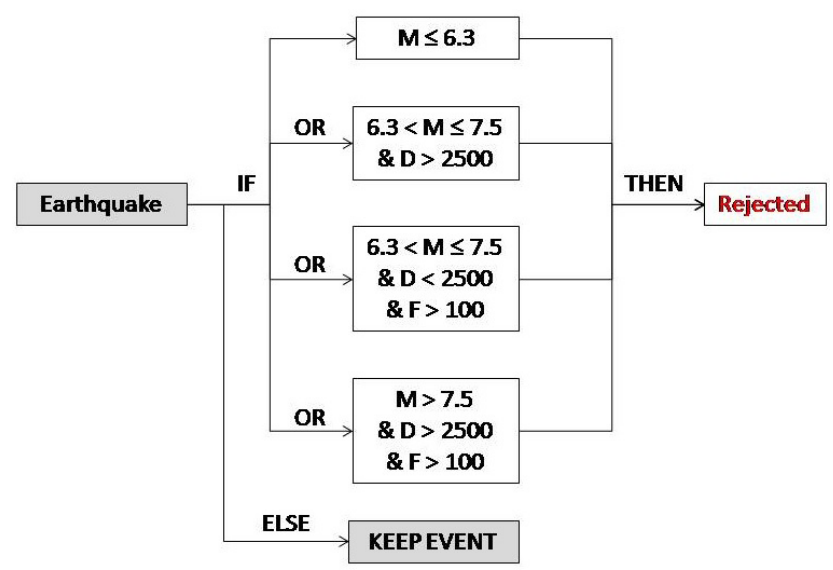

Figure 4. Decision table to select events automatically.

the present paper we show unpublished records of digitized high-frequency sea-level data.

All the tide gauges started recording high-frequency sea level (with sampling rates faster than $5 \mathrm{~min}$ ) only in 2010 or later. The tide gauge characteristics are summarized in Table 1 .

In addition to these tide gauges, several pressure gauges have also been installed by IRD in Poindimié, Ouvéa and Uitoe (Fig. 2) within the framework of the ReefTEMPS project (Varillon et al., 2018) or the EMIL project (Aucan et al., 2017b). Their characteristics are also summarized in Table 1.

Tide gauge and pressure data were detided by removing the predicted tide. The predicted tide was calculated with a harmonic analysis of the entire dataset available for each site, all of which were longer than 6 months. 
Table 1. Permanent tide gauge locations and pressure sensors in New Caledonia.

\begin{tabular}{|c|c|c|c|c|c|c|}
\hline Type & $\begin{array}{l}\text { Longitude } \\
\quad\left({ }^{\circ}\right)\end{array}$ & $\begin{array}{l}\text { Latitude } \\
\qquad\left(^{\circ}\right)\end{array}$ & Name & $\begin{array}{l}\text { In-operation } \\
\text { date }\end{array}$ & $\begin{array}{l}\text { First available high-frequency } \\
(<5 \text { min) observation }(\mathrm{SHOM})\end{array}$ & $\begin{array}{l}\text { Date of last } \\
\text { available data }\end{array}$ \\
\hline $\begin{array}{l}\text { Tide } \\
\text { gauge } \\
\text { stations }\end{array}$ & $\begin{array}{l}166.436742 \\
166.241528 \\
167.278694 \\
166.561867 \\
166.683276 \\
167.877100 \\
164.943122 \\
166.416218\end{array}$ & $\begin{array}{l}-22.291478 \\
-21.613806 \\
-20.918472 \\
-20.549816 \\
-21.982877 \\
-21.547800 \\
-20.691993 \\
-22.241966\end{array}$ & $\begin{array}{l}\text { Chaleix (Nouméa) } \\
\text { Thio } \\
\text { Lifou } \\
\text { Ouvea } \\
\text { Ouinne } \\
\text { Mare } \\
\text { Hienghène } \\
\text { Numbo (Nouméa) }\end{array}$ & $\begin{array}{l}\text { 24 Feb } 1967 \\
\text { 9 Jun } 1967 \\
\text { 8 Sep } 1969 \\
6 \text { Apr } 1981 \\
\text { 30 Aug } 1981 \\
\text { 26 Oct } 1982 \\
\text { 13 Dec } 1983 \\
\text { 29 Jul } 2001\end{array}$ & $\begin{array}{l}\text { None except pre-1967 paper records } \\
23 \text { Apr } 2015 \\
22 \text { May } 2013 \\
27 \text { Oct } 2011 \\
17 \text { May } 2011 \\
22 \text { Apr } 2012 \\
23 \text { Feb } 2011 \\
7 \text { Oct } 2010\end{array}$ & 2005 \\
\hline $\begin{array}{l}\text { Pressure } \\
\text { sensors }\end{array}$ & $\begin{array}{l}166.183200 \\
166.488250 \\
165.322034 \\
165.484807\end{array}$ & $\begin{array}{l}-22.285866 \\
-20.653333 \\
-20.928805 \\
-20.891997\end{array}$ & $\begin{array}{l}\text { Uitoe_04 } \\
\text { Ouvéa_02 } \\
\text { Poindimié_Tieti } \\
\text { Poindimié_Fourmi }\end{array}$ & $\begin{array}{l}\text { 24 Jun } 2016 \\
\text { 23 Sep } 2013 \\
\text { 18 Sep } 2013 \\
1 \text { Nov } 2013\end{array}$ & $\begin{array}{l}24 \text { Jun } 2016 \\
23 \text { Sep } 2013 \\
1 \text { Nov } 2013 \\
1 \text { Nov } 2013\end{array}$ & $\begin{array}{l}\text { 14 Nov } 2018 \\
4 \text { Apr } 2014 \\
\text { 20 Jul } 2016 \\
\text { 15 May } 2017\end{array}$ \\
\hline
\end{tabular}

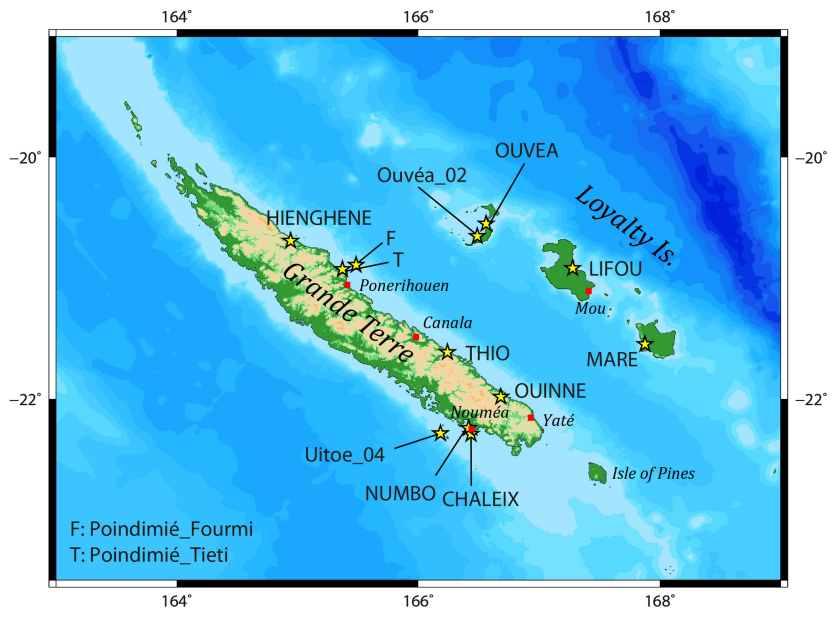

Figure 5. New Caledonia tide and pressure gauges (yellow stars).

\section{Tsunami catalogue}

The decision table has been able to extract 967 events $\left(M_{\mathrm{w}} \geq\right.$ 6.3) from the USGS earthquake catalogue that occurred between 1 January 1900 and 10 January 2019.

\subsection{Events after 29 September 2009}

\subsubsection{Extracted events present in the NOAA NGDC catalogue and recorded by tide gauges}

\section{a. Looking at the NOAA NGDC catalogue}

At first we decided to look only at the events that occurred after the period considered by Sahal et al. (2010), i.e., after the 29 September 2009 Samoa tsunami. This represents 113 from the 967 extracted events. But not all these events triggered a tsunami and even fewer a tsunami able to reach New Caledonia. To look at their tsunamigenic capa- bilities, this list of earthquakes was cross-compared with the NOAA NGDC/WDS Global Historical Tsunami Database, which provided 44 events that were reported as tsunamigenic (last download date: 24 August 2018). This list includes events like the 27 February 2010 Chile $M_{\mathrm{w}}=8.8$ or the 11 March 2011 Japan $M_{\mathrm{w}}=9.1$ earthquakes. The 44 tsunamigenic events represents $38.94 \%$ of the 113 events extracted from the USGS EQ database. For the period from 24 August 2018 to 10 January 2019, nine events were extracted from the USGS database with the decision table. Amongst them, only two were followed by a NOAA PTWC bulletin indicating they triggered a tsunami. Thus, there are $46(44+2)$ tsunamigenic events for the period from 29 September 2009 to 17 January 2019, corresponding to $40.71 \%$ of the 113 identified earthquakes. From these 46 events, only 14 were followed by a tsunami recorded in New Caledonia according to the observations included within PTWC bulletins.

An in-depth look at the other 32 events $(46-14)$ case by case has been performed to identify small tsunamis that could have been missed by PTWC analysis (i.e., not mentioned in bulletins), using the Tsunami Database, newspapers and tide gauge data from the eight local stations.

\section{b. Looking at tide gauge data}

From September 2009 to February 2011 only the Nouméa tide gauge (Numbo) operated at high enough frequency to record any potential tsunamis. Although eight extracted tsunamigenic earthquakes were reported by PTWC bulletins during this period, none were recorded by the Numbo tide gauge, even the $M_{\mathrm{w}}=8.8$ earthquake of 27 February 2010 that occurred in Biobio, Chile, recorded on nearby islands (Tonga, New Zealand, Australia, French Polynesia, etc.). For the period from February 2011 to January 2019, there are still $24(32-8)$ tsunamigenic events extracted from the list. Hienghène and Ouinné tide gauges have been chosen to iden- 
tify the corresponding recorded signals since these two tide gauges located on the east coast of the Grande Terre (Fig. 5) are exposed to several tsunami sources and are located in bays or estuaries that could amplify tsunami signals. Seven of these 24 tsunamis were recorded by the Ouinné gauge but not reported in New Caledonia by the PTWC.

For the 14 events reported by the PTWC in New Caledonia, only two of them were not recorded locally with certainty (probably an ambiguity in the background noise): the 18 July 2015 Solomon Islands and 20 August 2011 Vanuatu events. These two events are excluded.

Thus, there are $19(12+7)$ tsunamis that were recorded in New Caledonia between 30 September 2009 and 10 January 2019 with certainty. These 19 events are detailed in Table 2 .

\subsubsection{Only recorded by tide gauges}

An in-depth analysis of the sea-level data recorded by the Ouinné and Hienghène tide gauges for events extracted by the decision table but not reported as tsunamigenic in the NOAA NGDC catalogue allows us to find additional tsunamis that were recorded in New Caledonia between 30 September 2009 and 10 January 2019. Thus, of the 67 events (113-46) not identified as tsunamigenic by NOAA NGDC, 6 still produced tsunamis recorded by New Caledonia gauges. They are reported in Table 2 .

\subsubsection{Results}

Finally 25 new events $(19+6)$ were found. This represents a considerable update of the catalogue from Sahal et al. (2010). It is important to note that aftershocks of powerful tsunamigenic earthquakes, such as the $M_{\mathrm{w}}=7.8$ earthquake of 8 December 2016 that occurred in Kirakira, Solomon Islands, could also trigger tsunamis that would be drowned within the main shock tsunami signal. Also small tsunami signals could be covered by background noise, especially the coastal or offshore infragravity waves (Stephenson and Rabinovich, 2009; Aucan and Ardhuin, 2013).

\subsection{Events before 29 September 2009}

For the period before 29 September 2009, Sahal et al. (2010) collected 18 events, including 12 events related with certainty to an identified earthquake. These 12 events are detailed in Table 3. There is a strong uncertainty in the accuracy of the 6 other reported events concerning the date as well as the source.

Eleven out of the 12 seismic events reported by Sahal et al. (2010) and shown in Table 3 have been kept with the decision table; the first one from 1875 is beyond the range of the USGS database beginning on 1 January 1900. These 11 events are part of the 854 extracted events by the decision table for the period from 1 January 1900 to 29 September 2009 (inclusive). This represents less than $1.29 \%$ of earthquakes of magnitude $M_{\mathrm{w}} \geq 6.3$ being able to produce a tsunami reaching New Caledonia over this period.

In comparison, for the period from 30 September 2009 to 10 January 2019,25 of the 113 events extracted with the decision table produced a tsunami that reached New Caledonia. This represents $22.12 \%$ of the earthquakes of magnitude $M_{\mathrm{w}} \geq 6.3$.

\subsection{Comparison of the two periods}

Even if we only consider the tsunamis reported in the NOAA NGDC catalogue, it corresponds to 11 out of 854 events for the 100-year period from 1 January 1900 to 29 September 2009 (included) and 14 out of 113 events for the 10year period from 30 September 2009 to 10 January 2019, i.e., $1.29 \%$ and $12.39 \%$, so an increase by a factor of 10 . This is likely due to the lack of tide gauge data before 2009 , highlighting the importance of sea-level data.

Indeed, to compare the two periods exactly, we should consider the same number of days, i.e., 9 years, 3 months and $10 \mathrm{~d}$. Thus for the period from 19 June 2000 to 29 September 2009 the decision table extracted 111 events potentially able to trigger tsunamis able to reach New Caledonia (this number is very close to the 113 events extracted after 29 September 2009 and to the 96 events extracted from 9 March 1991 to 19 June 2000). Cross-comparing those 111 events to the NOAA NGDC tsunami database, it appears that 26 earthquakes triggered a tsunami in the Pacific Ocean, either locally, regionally or transoceanically. And from these 26 events, only 4 were reported in New Caledonia according to Sahal et al. (2010).

\subsection{Individual events during the 2009-2019 period}

During this period, some events are particularly interesting as their records demonstrate the importance of local tide gauges and pressure sensors in tsunami hazard studies.

\subsubsection{February 2013 Solomon Islands tsunami}

The tsunami generated by the $M_{\mathrm{w}}=8.0$ earthquake that occurred on 6 February 2013 at 01:12:25 UTC in Santa Cruz, Solomon Islands, was recorded by the Lifou tide gauge at almost 03:00 UTC (02:00 LT - local time) and well observed by local witnesses (Fig. 6). The two pictures shown in Fig. 6 were taken during the first wave maximum (a) and the following minimum (b).

\subsubsection{September 2015 Chile tsunami}

On 16 September 2015 at 22:54:32 UTC a magnitude $M_{\mathrm{w}}=$ 8.3 earthquake in the region of Illapel, Chile, triggered a transoceanic tsunami. After hours of propagation, it reached most of the South Pacific Ocean tide gauges. In New Caledonia it was recorded by permanent tide gauge stations and pressure gauges about $16 \mathrm{~h}$ after the earthquake, as shown in 


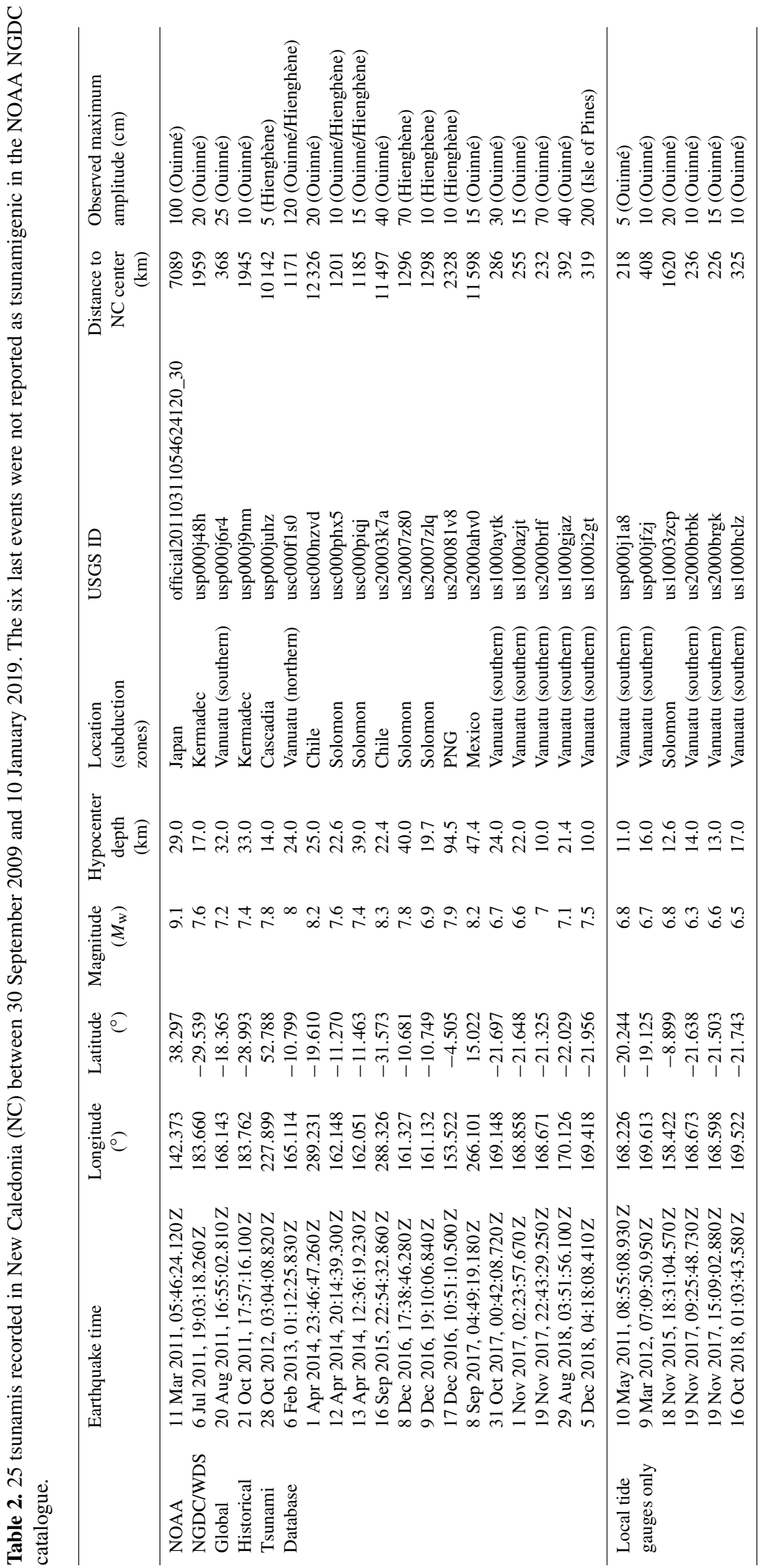




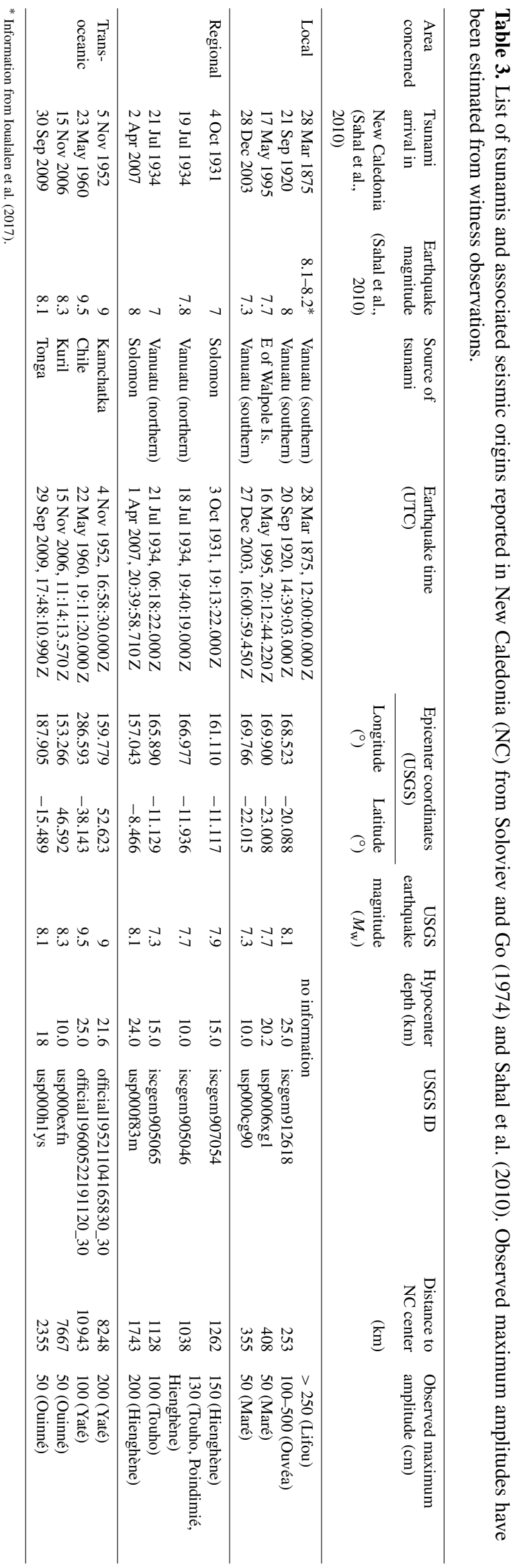

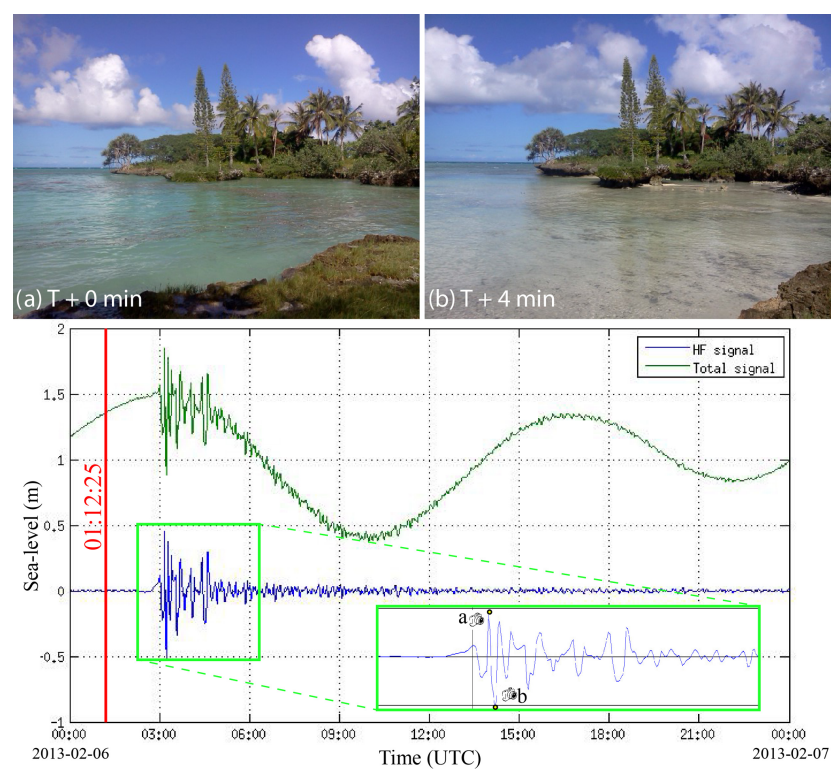

Figure 6. The 6 February 2013 Solomon Islands tsunami record from Lifou tide gauge (green: raw signal; blue: filtered). The red line locates the earthquake time. The two pictures were taken at Mou (on the southeastern coast of Lifou) at the maximum (a) and minimum (b) sea levels. The green inset focuses on the main tsunami signal (photos courtesy of Matthieu Le Duff).

Fig. 7. This event is particularly interesting in the sense it confirms clearly that tsunamis are amplified near the Ouinné tide gauge, more than at the other gauges (except Hienghène where unfortunately the beginning of the record is missing). At Poindimié two pressure gauges installed outside of the lagoon (Poindimié_Fourmi) and inside the lagoon close to the shore (Poindimié_Tieti) also recorded the tsunami. Data from the two gauges show the wave shoaling and probably also the amplification (up to 5 times) due to resonance inside the lagoon. Also, during this event a pressure gauge was rapidly installed at the Chaleix Naval Base at the location of the discontinued Chaleix tide gauge to compare the recorded signal to the Numbo tide gauge signal. The recorded signal at Chaleix was nearly 3 times higher than at Numbo's despite the close proximity of the two sites (for location details, see Aucan et al., 2017a).

\subsubsection{November 2017 southern Vanuatu tsunami}

Another example is given by three earthquakes that occurred during the 19 November 2017 seismic crisis that occurred east of Mare Island: two very small tsunamis were triggered by the $M_{\mathrm{w}}=6.3$ and 6.6 foreshocks of the $M_{\mathrm{w}}=7.0$ earthquake, which triggered a tsunami reaching a maximum amplitude of $0.8 \mathrm{~m}$ at Ouinné tide gauge. Despite their small amplitude, they are very well recorded and shown in Fig. 8 . 


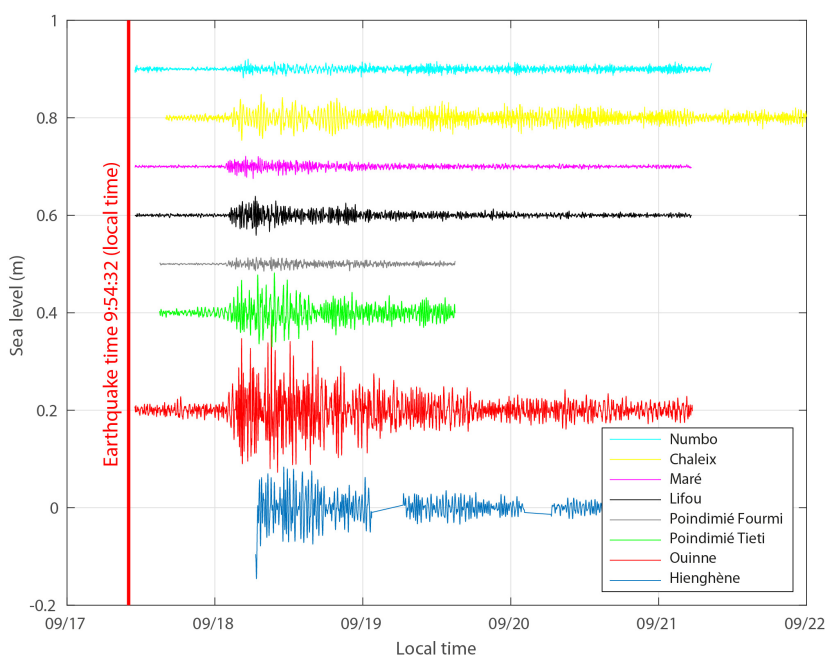

Figure 7. Sea-level variations recorded by tide and pressure gauges in New Caledonia following the 16 September 2015 earthquake that occurred in Illapel, Chile.

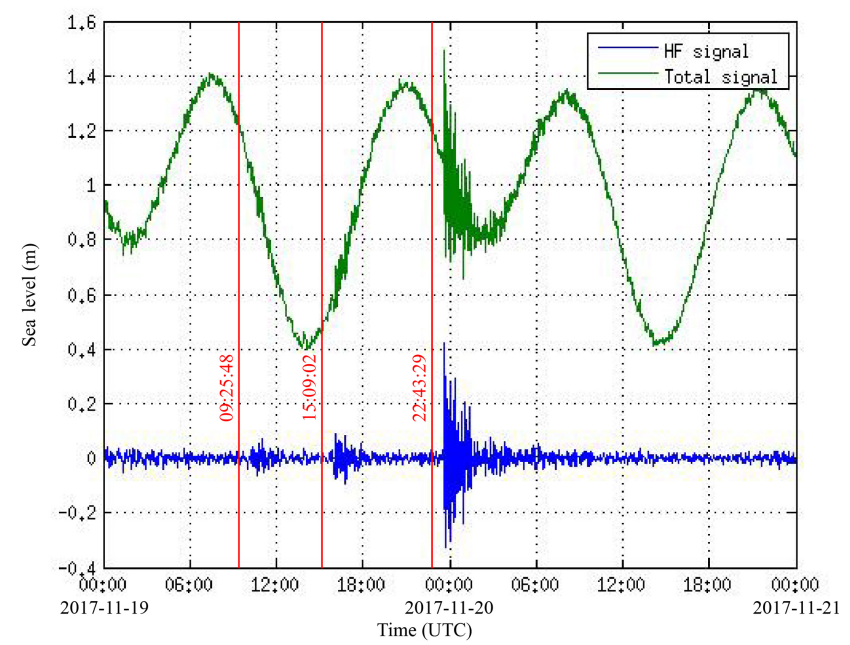

Figure 8. The triplet of tsunamis of 19 November 2017 recorded by the Ouinné tide gauge. The blue graph shows the filtered signal without the tide (the tide signal is visible on the green graph). The red lines show the times of the three different earthquakes.

\subsubsection{December 2018 Vanuatu tsunami}

On 5 December 2018, a magnitude $M_{\mathrm{w}}=7.5$ earthquake occurred at 04:18:08 UTC in the south of the Vanuatu subduction zone. Widely felt by the population in New Caledonia but also in Vanuatu, a tsunami was soon recorded, firstly by the Loyalty Islands tide gauges (Maré and Lifou) and by all the other tide gauges within $1 \mathrm{~h} 30 \mathrm{~min}$ after the main shock (Fig. 9). As it sometimes reached heights more than $1 \mathrm{~m}$ according to eyewitnesses, this tsunami was also observed by numerous people, for example, in Yaté, close to Ouinné, on the southeast coast of Grande Terre (Fig. 10a) and on the east

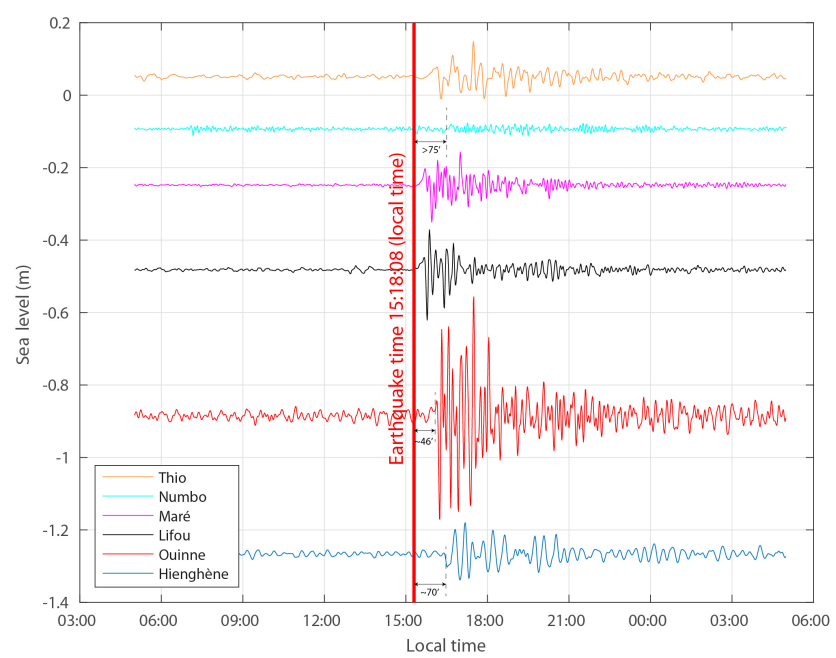

Figure 9. Sea-level variations recorded by tide and pressure gauges in New Caledonia following the 5 December 2018 Vanuatu earthquake.

coast of the Isle of Pines around the Méridien Resort and the Natural Pool touristic site where people were evacuated (Fig. 10b).

\subsection{Additional information on previously reported events}

Five other events could likely be added to the catalogue. They come from testimonies and regional records (some of them have been already discussed in Sahal et al., 2010).

\subsubsection{Testimonies of tsunami events with unspecified dates and not closely linked in time with any earthquakes}

The 1936 event reported in the northeast of the Grande Terre (north of Hienghène) with a 2 to $3 \mathrm{~m}$ run-up could be due to a local landslide or possibly may be linked to the July 1934 northern Vanuatu earthquake $\left(M_{\mathrm{w}}=7.8\right)$ which triggered a tsunami observed in the same region (Hienghène-Touho).

The May-July 1942 or 1943 large wave reported in Hienghène (2.5 m run-up) and possibly the flooding around 1940 reported on the Isle of Pines ( $2 \mathrm{~m}$ run-up) could be attributed to the same major event (although the link between these reports is uncertain). No link could be made between these time periods and any earthquake. These events could have been the result of landslides.

\subsubsection{Testimonies of an event with unspecified date but that can be linked to a major local earthquake}

The December 1950-February 1951 swelling and tidal wave reported at different localities by Sahal et al. (2010) along the east coast of the Grande Terre (Hienghène, Poindimié, Ponérihouen, Canala) and on the Isle of Pines (Fig. 5) could 

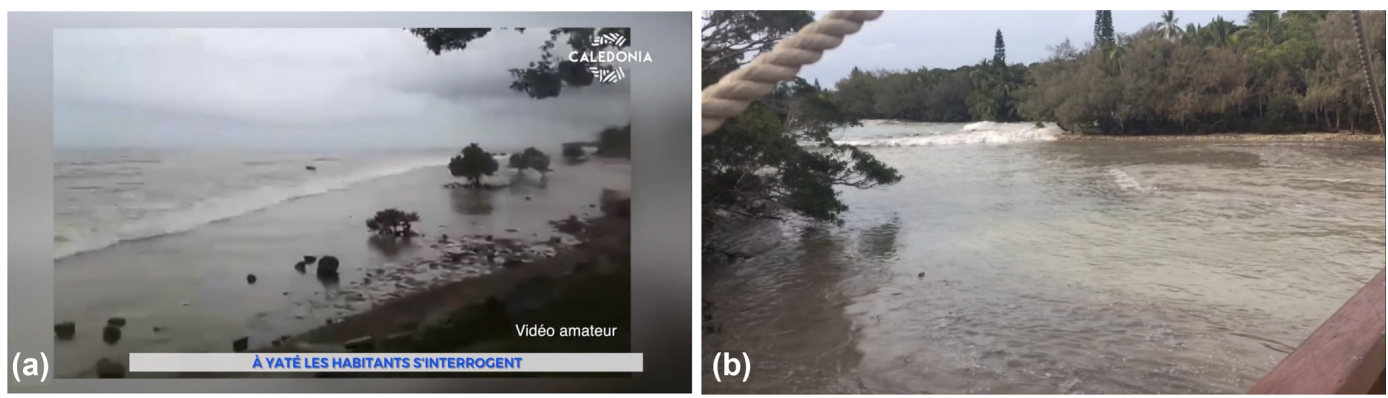

Figure 10. Arrival of the 5 December 2018 tsunami in (a) Yaté after the first withdrawal of the sea (courtesy of Rose-Mai Néa) and (b) at the bridge linking the Méridien resort island to the Isle of Pines (courtesy of Moana Bretault).

be linked either to the 2 December 1950 large southern Vanuatu earthquake $\left(M_{\mathrm{w}}=7.9\right)$, which is one the largest events located close to New Caledonia and which generated a tsunami observed in Port Vila, Vanuatu (Louat and Baldassari, 1989), or to the 26-27 February 1951 storm tide.

\subsubsection{No record or testimony of worldwide or basin-wide events which are recorded, especially in the vicinity of New Caledonia}

The 26 December 2004 Indonesian tsunami $\left(M_{\mathrm{w}}=9.1\right.$ Sumatra earthquake) and the 27 February 2010 Chilean tsunami $\left(M_{\mathrm{w}}=8.8\right.$ Maule earthquake $)$ were not reported in New Caledonia, although they were well recorded in Tonga, New Zealand and Australia. The reason is probably the fact that there was only one tide gauge operating in Nouméa in 2004 (e.g., Chaleix, sampled at a frequency of $1 \mathrm{~h}$ ) and in 2010 (e.g., Numbo, sampled at a frequency of $10 \mathrm{~min}$ ).

\subsubsection{May 1960 Chile tsunami}

Although it was already included within the catalogue from Sahal et al. (2010), the Great Chilean tsunami of 1960 was only reported through witness observations. Here we present a historical marigraphic record recovered in the SHOM archive, that shows this transoceanic tsunami was recorded in Nouméa by the Chaleix tide gauge (Fig. 11). The tsunami amplitude is about $30 \mathrm{~cm}$ for the two primary waves.

\section{Discussion and conclusion}

\subsection{Limitations of the methodology}

This methodology using an extraction decision table is based only on the reported or recorded tsunamis generated by earthquakes and, thus, does not consider tsunamis triggered by landslides or, less frequently, by volcanic eruptions, representing about $7 \%$ and $5 \%$, respectively, of the reported tsunamis of the NOAA tsunami database according to Harbitz et al. (2014). In the available data, there is no evidence of tsunamis related to active volcanism or landslides. Any- way, active submarine volcanoes exist in the neighborhood of New Caledonia, especially off the Loyalty Islands (Gemini seamounts, $200 \mathrm{~km}$ east of Maré and south of Aneytum, Vanuatu) on the Vanuatu volcanic arc. In addition, numerous submarine landslides have been mapped along the margins of Grande Terre and the Loyalty Islands.

Another limitation comes from the fact that we do not consider the tsunami amplitudes in this study. In fact, it is very difficult to estimate a maximum value for each event in New Caledonia because of an obvious lack in field observations for each one and an absence of tide gauges in specific places, like the Isle of Pines where important tsunami run-ups have been reported for at least the 5 December 2018 event. A tsunami could have been weakly recorded by a tide gauge located in a protected area, for example in Nouméa harbor, although it had a strong impact on an exposed coast, for example, on the east coast of the Isle of Pines. In addition, as detailed by Ioualalen et al. (2017), a resonance phenomenon seems to play a predominant role in the tsunami behavior, especially in the Loyalty Islands, depending directly on the source location and geometry. So, information concerning maximum observed amplitudes mentioned in Tables 2 and 3 gives just an idea of what happened during the reported events.

\subsection{Contributions to tsunami hazard assessment and risk management}

The 25 events are added to the 12 events from Sahal et al. (2010), leading to a list of 37 tsunamis reported or recorded for New Caledonia over the last 144 years. In addition to the 1875 event (no exact location available), the 36 earthquake epicenters are shown in Fig. 12. As expected, it highlights five different tsunamigenic zones able to trigger tsunamis toward New Caledonia: locally, the Vanuatu subduction zone is responsible for $17 / 37$ tsunamis, i.e., $45.94 \%$; at a regional scale, the Tonga-Kermadec subduction zone triggered $3 / 37$ tsunamis, i.e., $8.1 \%$, and the Solomon/Papua New Guinea subduction zone is responsible for $9 / 37$, i.e., $24.32 \%$; and at an ocean scale the transoceanic tsunamis represent $8 / 37$ events, i.e., $21.62 \%$. 


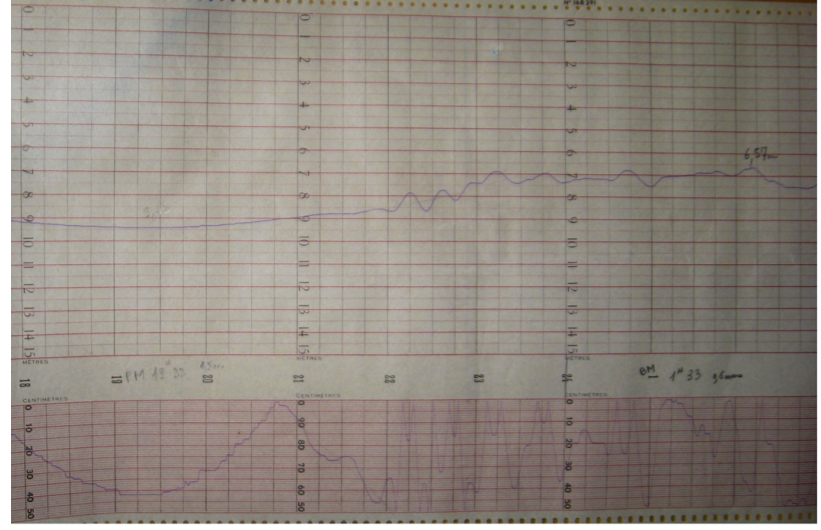

(a)

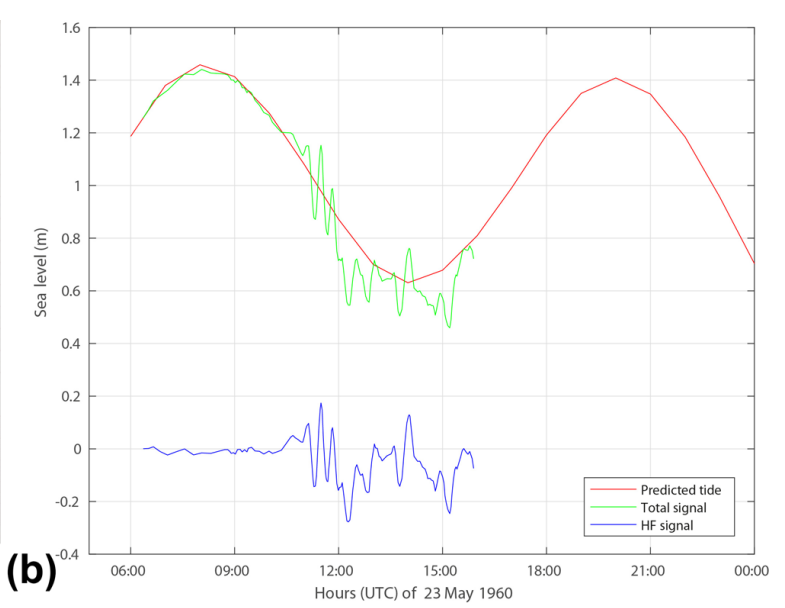

Figure 11. Tide gauge record of the 22 May 1960 Chile tsunami in Nouméa (Chaleix station): original record (a) and digitized signal (b), total (in green) and detided (in blue).
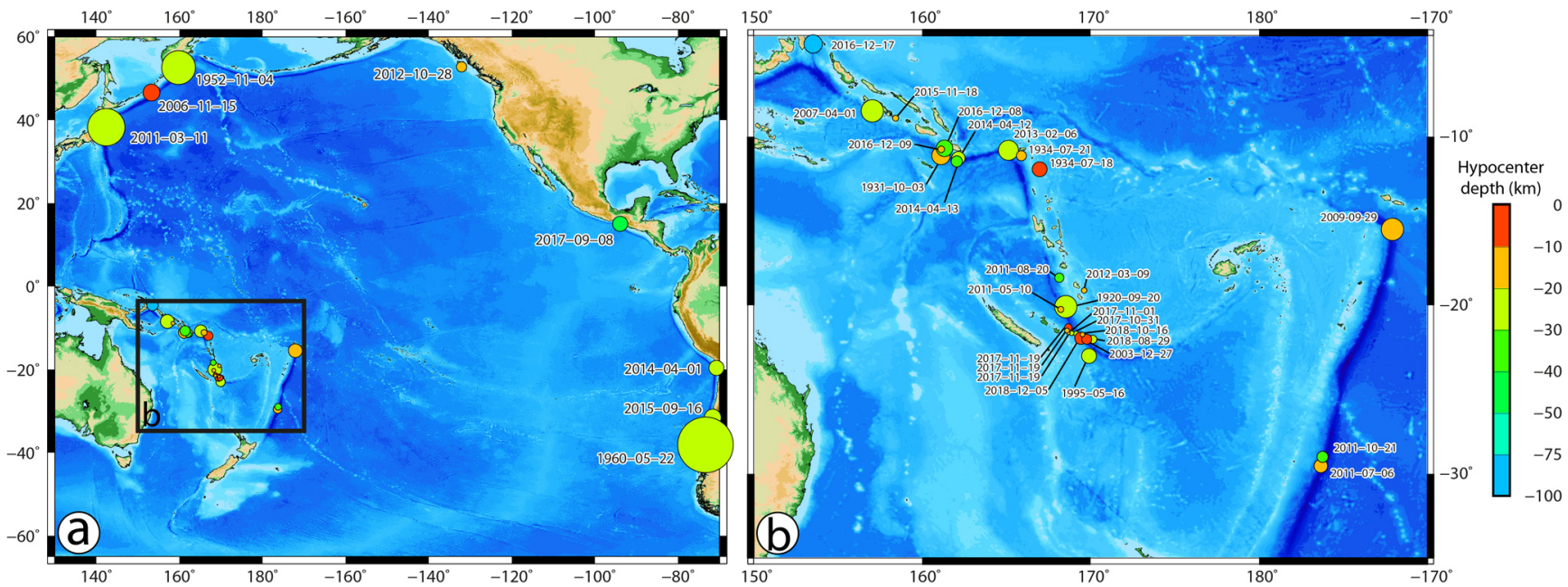

Figure 12. Location of the epicenter of earthquakes that triggered tsunamis reported or recorded in New Caledonia. (a) Over the whole Pacific Ocean highlighting source locations of transoceanic tsunamis and (b) at a regional scale, highlighting regional and local sources.

Besides the 17 December 2016 PNG $M_{\mathrm{w}}=7.9$ earthquake of which hypocenter has been located to be $\sim 100 \mathrm{~km}$ deep, the hypocenters of the other earthquakes are located to be not deeper than $50 \mathrm{~km}$.

Concerning tsunami amplitudes, their observed range varies from a few centimeters to several meters. Local tsunamis caused by southern Vanuatu earthquakes impact mainly the Loyalty Islands and the southeast coast of Grande Terre (including the Isle of Pines) and are the most frequent and strongest. The northeastern part of Grande Terre is more impacted by regional tsunamis coming from the north (Solomon and northern Vanuatu subduction zones). Transoceanic tsunamis are also important to be considered in New Caledonia, as they are able to reach heights of 1-2 m locally.
A graphic representation of the 36 earthquakes showing magnitude $\left(M_{\mathrm{w}}\right)$ as a function of the distance between the epicenter location and the center of New Caledonia highlights three different groups (Fig. 13): the group of eight earthquakes on the right corresponds unsurprisingly to the transoceanic tsunamis; the group on the left corresponds to the local events from the southern Vanuatu subduction zone; and the central group corresponds to the regional events (Solomon Islands, northern Vanuatu and Tonga). In terms of risk management, this study brings new constraints on alert thresholds:

- In a local field, with an epicenter located within a distance less than $500 \mathrm{~km}$, only a magnitude $M_{\mathrm{w}} \geq 6.3$ earthquake is able to trigger a tsunami that can be reported along New Caledonia coastlines. 


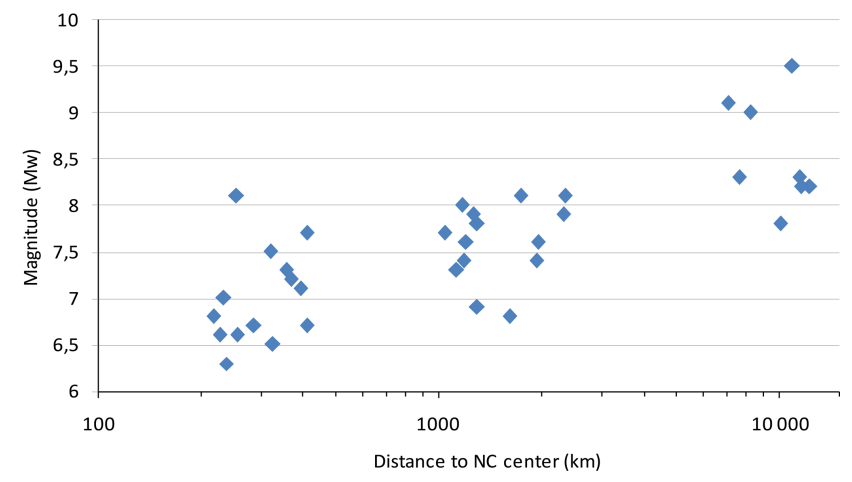

Figure 13. Graphic representation of the new catalogue showing earthquake's magnitude $\left(M_{\mathrm{W}}\right)$ as functions of distance between epicenter and New Caledonia (NC).

- At a regional scale, i.e., at a distance of more than $1000 \mathrm{~km}$, only earthquakes with magnitude $M_{\mathrm{w}} \geq 6.7$ would be considered as being potentially hazardous for New Caledonia in terms of tsunami waves and currents.

- At a far-field location, i.e., at a distance of more than $6000 \mathrm{~km}$, only earthquakes with magnitude $M_{\mathrm{w}} \geq 7.7$ would be considered as being potentially hazardous for New Caledonia in terms of tsunami waves and currents.

\subsection{Conclusion}

This study allows the tsunami catalogue of New Caledonia to be completed with 25 new events of seismic origin for the period between 30 September 2009 and 10 January 2019: 19 already identified in the NOAA NGDC tsunami catalogue and 6 others recorded by New Caledonia gauges but not reported either in the NOAA NGDC catalogue or within the NOAA PTWC bulletins. The New Caledonia tsunami catalogue now consists of 37 tsunamis. The study also emphasizes that there is a considerable lack of tsunami information in New Caledonia for the pre-September 2009 period concerning medium-magnitude events, due to the fact that there were few or no tide gauges and DART buoys able to record small tsunamis. Note that there is no study dealing with paleotsunamis in New Caledonia.

Finally, this study clearly highlights the value of tide gauge records, including old paper ones, and the necessity of setting up the gauges in well-identified locations, i.e., not always in sheltered areas but rather in places facing main tsunami pathways. It also brings to light the necessity of installing more sensors in exposed areas like on the east coast of the Isle of Pines.

Data availability. This paper does not have underlying research data. All the datasets used herein, such as the USGS, the NOAA or the Russian catalogues are indicated in the paper, as well as the marigraphic data from ReefTEMPS or REFMAR projects. The new data provided by this paper are given in the New Caledonia tsunami catalogue (presented in the paper) and the wave amplitudes indicated in Tables 2 and 3.

Author contributions. JR, BP and JA conceived this study. JR collected and analyzed all data and prepared the figures. JR and $\mathrm{BP}$ wrote the paper with assistance and input from JA.

Competing interests. The authors declare that they have no conflict of interest.

Acknowledgements. This study is part of a national project of tsunami hazard assessment (TSUCAL) funded by the local government of New Caledonia. The authors would like to thank the SHOM for providing tide gauge data (http://doi.org/10.17183/ REFMAR, last access: January 2019) and the ReefTEMPS coastal sea waters' observation network for providing pressure gauge data (http://doi.org/10.17882/55128, last access: January 2019). They would also like to acknowledge the constructive comments of Viacheslav K. Gusiakov, two anonymous referees and the editor Maria Ana Baptista.

Review statement. This paper was edited by Maria Ana Baptista and reviewed by two anonymous referees.

\section{References}

Aucan, J. and Ardhuin, F.: Infragravity waves in the deep ocean: An upward revision, Geophys. Res. Lett., 40, 3435-3439, https://doi.org/10.1002/grl.50321, 2013.

Aucan, J., Merrifield, M. A., and Pouvreau, N.: Historical sea level in the South Pacific from rescued archives, geodetic measurements and satellite altimetry, Pure Appl. Geophys., 174, 38133823, https://doi.org/10.1007/s00024-017-1648-1, 2017a.

Aucan, J., Vende-Leclerc, M., Dumas, P., and Bricquir, M.: Wave forcing and morphological changes of the New Caledonia lagoon islets, Comptes Rendus Geosciences, 349, 248-259, https://doi.org/10.1016/j.crte.2017.09.003, 2017b.

Bevis, M., Taylor, F. W., Schuz, B. E., Recy, J., Isacks, B. L., Helu, S., Singh, R., Kendrick, E., Stowell, J., Taylor, B., and Calmant, S.: Geodetic observations of very rapid convergence and backarc extension at the Tonga arc, Nature, 374, 249-251, 1995.

Bolt, B. A., Horn, W. L., Macdonald, G. A., and Scott, R. F.: Geological Hazards, in: Earthquakes - Tsunamis - Volcanoes Avalanches - Landslides -Floods, Springer-Verlag, New York, USA, 329 pp., https://doi.org/10.1007/978-3-642-86820-7, 1975.

Borrero, J. C., Legg, M. R., and Synolakis, C. E.: Tsunami sources in the southern California bight, Geophys. Res. Lett., 31, L13211, https://doi.org/10.1029/2004GL020078, 2004.

Calmant, S., Pelletier, B., Bevis, M., Taylor, F., Lebellegard, P., and Phillips, D.: New insight on the tectonics of the New Hebrides subduction zone based on GPS results, J. Geophys. Res., 108, 2316, https://doi.org/10.1029/2001JB000644, 2003. 
DeMets, C., Gordon, R. G., and Argus, D. F.: Geologically current plate motions, Geophys. J. Int., 181, 1-80, https://doi.org/10.1111/j.1365-246X.2009.04491.x, 2010.

Faivre, J.-P.: Les origines de la colonisation française en NouvelleCalédonie, d'après un travail récent, Journal de la Société des océanistes, 6, 241-247, 1950.

Forestier, H.: Contribution à la connaissance du peuplement du Pacifique Sud-Ouest, in: L'industrie lithique des premiers mélanésiens de Nouvelle-Calédonie: Etude du site de Naia (Province sud) et quelques éléments de comparaison avec la région de Koumac (Province nord), Mémoire de D.E.A., Institut de Paléontologie Humaine, MNHN, Paris, 98 pp., 1994.

Glimsdal, S., Pedersen, G. K., Harbitz, C. B., and Løvholt, F.: Dispersion of tsunamis: does it really matter?, Nat. Hazards Earth Syst. Sci., 13, 1507-1526, https://doi.org/10.5194/nhess13-1507-2013, 2013.

Harbitz, C. B., Løvholt, F., and Bungum, H.: Submarine landslide tsunamis: how extreme and how likely?, Nat. Hazards, 72, 13411374, https://doi.org/10.1007/s11069-013-0681-3, 2014.

Ioualalen, M., Pelletier, B., and Solis Gordillo, G.: Investigating the March 28th 1875 and the September 20th 1920 earthquakes/tsunamis of the Southern Vanuatu arc, offshore Loyalty Islands, New Caledonia, Tectonophysics, 709, 20-38, https://doi.org/10.1016/j.tecto.2017.05.006, 2017.

Legg, M. R. and Borrero, J. C.: Tsunami potential of major restraining bends along submarine strike-slip faults, in: ITS 2001 Proceedings, Number 1-9, session 1, 7-10 August 2001, Seattle, Washington, USA, 331-342, 2001.

Louat, R. and Baldassari, C.: Chronologie des séismes et des tsunamis ressentis dans la région Vanuatu NouvelleCalédonie (1729-1989), Rapports Scientifiques et Techniques, Sciences de la Terre, ORSTOM Nouméa, 1, 48 pp., 1989.

Pelletier, B. and Louat, R.: Mouvements relatifs des plaques dans le Sud-Ouest Pacifique, C. R. Acad. Sci. Paris, 308, 123-130, 1989.

Pelletier, B., Calmant, S., and Pillet, R.: Current tectonics of the Tonga-New Hebrides region, Earth Planet. Sc. Lett., 164, 263 276, 1998.

Rabinovich, A. B. and Thomson, R. E.: The 26 December 2004 Sumatra tsunami: analysis of tide gauge data from the World Ocean Part 1. Indian Ocean and South Africa, in: Tsunami and its hazards in the Indian and Pacific Oceans, edited by: Satake, K., Okal, E. A., and Borrero, J. C., Birkhäuser Verlag, Basel, 261-308, https://doi.org/10.1007/s00024-006-0164-5, 2007.

Rabinovich, A. B., Candella, R. N., and Thomson, R. E.: The open ocean energy decay of three recent transPacific tsunamis, Geophys. Res. Lett., 40, 3157-3162, https://doi.org/10.1002/grl.50625, 2013.
Sahal, A., Pelletier, B., Chatelier, J., Lavigne, F., and Schindelé, F.: A catalog of tsunamis in New Caledonia from 28 March 1875 to 30 September 2009, Comptes Rendus Geoscience, 342, 434 447, https://doi.org/10.1016/j.crte.2010.01.013, 2010.

Soloviev, S. L. and Go, C. N.: A catalogue of tsunamis on the western shore of the Pacific Ocean (173-1968) (Canadian Translation of Fisheries and Aquatic Sciences, 5077, 1984), Nauka Publishing House, Moscow, USSR, 310 pp., 1974.

Stephenson, F. E. and Rabinovich, A. B.: Tsunamis on the Pacific Coast of Canada recorded in 1994-2007, Pure Appl. Geophys., 166, 177-210, https://doi.org/10.1007/s00024-008-04407, 2009

Tanioka, Y. and Satake, K.: Tsunami generation by horizontal displacement of ocean bottom, Geophys. Res. Lett., 23, 861-864, https://doi.org/10.1029/96GL00736, 1996.

Tanioka, Y., Cabrera Ramirez, A. G., and Yamanaka, Y.: Simulation of a dispersive tsunami due to the $2016 \mathrm{El}$ Salvador-Nicaragua outer-rise earthquake (Mw 6.9), Pure Appl. Geophys., 175, 1363-1370, https://doi.org/10.1007/s00024-018-1773-5, 2018.

Tinti, S.: Evaluation of tsunami hazard in Calabria and Eastern Sicily, Italy, in: Tsunamis in the World, edited by: Tinti, S., Springer, Dordrecht, 141-157, 1991.

Titov, V., Rabinovich, A. B., Mofjeld, H. O., Thomson, R. E., and Gonzalez, F. I.: The global reach of the 26 December 2004 Sumatra tsunami, Science, 309, 2045-2048, https://doi.org/10.1126/science.1116505, 2005.

UNESCO/IOC: Operational Users Guide for the Pacific Tsunami Warning and Mitigation System (PTWS), IOC Technical Series, No. 87, 2nd Edn., 2009.

US Geological Survey: Earthquake catalog, available at: https: //earthquake.usgs.gov/earthquakes/search/, last access: 10 January 2019.

Varillon, D., Fiat, S., Magron, F., Allenbach, M., Hoibian, T., De Ramon N'Yeurt, A., Ganachaud, A., Aucan, J., Pelletier, B., and Hocdé, R.: ReefTEMPS: the observation network of the coastal sea waters of the South, West and South-West Pacific, SEANOE, https://doi.org/10.17882/55128, 2018.

Walker, D. A.: Ocean-wide tsunamis, magnitude thresholds, and 1946 type events, Sci. Tsunami Hazards, 23, 3-8, 2005.

Ward, S.: Relationships of tsunami generation and an earthquake source, J. Phys. Earth, 28, 441-74, https://doi.org/10.4294/jpe1952.28.441, 1980. 